\title{
Analysis of causes of structural failures of buildings using TQC tools
}

\author{
Agnieszka Czajkowska ${ }^{1, *}$ \\ ${ }^{1}$ Kielce University of Technology, Kielce, Poland
}

\begin{abstract}
This paper analyses structural failures of buildings over a period of ten years. Particular attention was paid to the analysis of structural failures caused by human mistakes. The analysis was performed according to two criteria: the stage of the building's life cycle and the type of works conducted in the area of the building site. The analysis was performed using a quality management tool (histogram and Pareto-Lorenza diagram), which allowed for identification of the causes responsible for the highest number of events. The analysis showed that three causes account for $64,61 \%$ of the structural failures that occurred.
\end{abstract}

\section{Introduction}

According to Article 73 of the Construction Law, a structural failure of building means unintentional, violent destruction of a building or its parts and structural components of scaffoldings, shape-forming components, sheet piling and excavation support. [1-3] Structural failures of buildings are often tragic. However, a damage to an embedded component of a building that can be repaired or replaced, damage to or destruction of building equipment connected to buildings, and installation failure are not considered a structural failure.

The District Building Supervision Inspector is responsible for qualification of a structural failure in case of sudden destruction of the building (structure) or its parts (even without fatalities), organizing a commission and an investigation in order to explain the causes and consequences of the damage during the accident [4].

In general, the causes of structural failure can be divided into:

- direct and indirect,

- technical, organizational, social,

- random, such as wind, precipitation, earthquakes and quakes caused by human activity at different stages of the building's life cycle.

The paper reviews the causes of structural failures in 2007-2017. Next, the causes of structural failures which were not related to the so-called random events in 2013-2017 were discussed. The aim of the analysis was to identify human mistakes which are most responsible for structural failures. The tools / methods used belong to the group of methods used in TQC [5]. They are used to collect and process information, to supervise and improve. They are used to graphically visualize the phenomenon and analyze the problem.

*Corresponding author: a_czajkowska@o2.pl 
The results from the analyzes are the starting point for diagnosis and prevention $[5,6]$.

They can be used in many areas of life.

TQC tools are mainly used for [5, 7]:

- creating ideas,

- description and analysis,

- identifying threats and problems,

- identification and analysis of causes

- identification and choice of solutions,

- implementation and evaluation of effectiveness.

The quality management tool (Histogram and Pareto chart) was used for the purpose.

\section{Causes of structural failures}

\subsection{Classification of causes of structural failures}

Structural failures are mostly related to random events such as heavy rains, excessive snow, fires, gas explosions, paraseismic vibrations, etc. Accidents not related to random factors account for from 12 to even $60 \%$ of all accidents. In order to evaluate the extent of a construction disaster, it should be linked to the damage it caused. By definition, a structural failures of buildings with the severity of the damage and always involves physical or nonphysical loss. The analysis of the causes of structural failures is aimed at reducing or completely eliminating the factors leading to a construction accident.

Figure 1 presents data on the frequency of structural failures over a period of ten years in Poland. The data were derived from the reports of the Central Office of Construction Supervision (COCS) [8]. The incidence of structural failures is presented in the form of a histogram. This chart is considered one of the seven basic tools of total quality management (TQM).

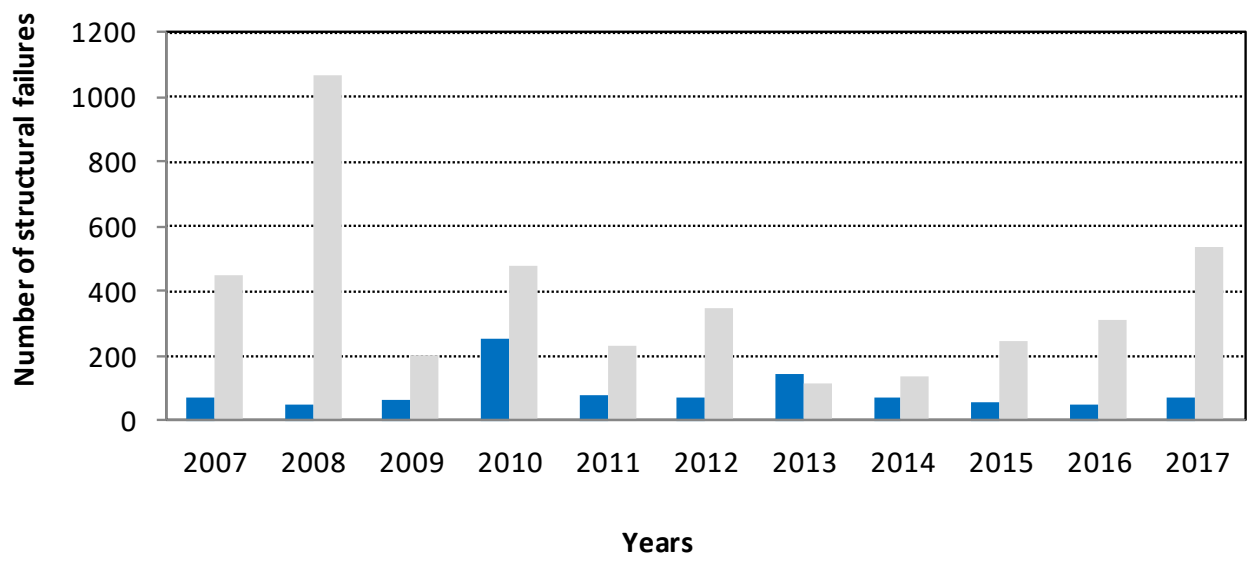

- Structural failures due to human mistakes Structural failures caused by random causes

Fig. 1. Structural failures caused by human mistakes and structural failures caused by random causes [COCS report]. 
The analysis shows that structural failures that are not the result of human mistakes constitute $12-60 \%$ of all. The structural failures caused by random events was the highest in 2008 (over 1000), while the structural failures resulting from human mistakes were the highest in 2010 .

In 2013, structural failures caused by human mistake were more than resulting from random events. We have a greater influence on the causes of structural failures resulting from human guilt than those resulting from random events.

In order to eliminate the causes of structural failures, the human side should only take into account those associated with:

- Building contractors (construction, assembly),

- Non-construction contractors (other industries),

- Designers,

- Manufacturers of materials and prefabricates,

- Users.

In the analysis we omit other random factors and exceptional loads, such as: rain, snow, hurricane etc.

\subsection{Analysis of the causes of structural failures resulting from human mistakes}

Particular focus of the study was on accidents resulting from human mistakes. From the standpoint of the possibility to eliminate or at least minimize the frequency of occurrence of structural failures, the failures were analysed according to two different criteria:

- building's life cycle,

- type of construction works carried out,

The first criterion concerns the building's life cycle. There are three types of mistakes:

- mistakes during maintenance of the building,

- mistakes during the construction of a new building or in the execution of other construction works in an existing building,

- mistakes in the preparation of the construction documentation.

Table 1. Human mistakes in the three stages of the construction life cycle.

\begin{tabular}{|c|l|c|c|c|c|c|}
\hline Symbol & \multicolumn{1}{|c|}{ Kind of mistake } & 2017 & 2016 & 2015 & 2014 & 2013 \\
\hline M1 & $\begin{array}{l}\text { mistakes during maintenance } \\
\text { of the building }\end{array}$ & 42 & 39 & 38 & 44 & 70 \\
\hline M2 & $\begin{array}{l}\text { mistakes during the } \\
\text { construction of a new } \\
\text { building or in the execution of } \\
\text { other construction works in an } \\
\text { existing building }\end{array}$ & 26 & 8 & 19 & 23 & 16 \\
\hline M3 & $\begin{array}{l}\text { mistakes in the preparation of } \\
\text { the construction } \\
\text { documentation }\end{array}$ & 1 & 2 & 23 & 1 & 1 \\
\hline
\end{tabular}

Data according to this criterion is summarized in Table 1.

Figure 2 presents the percentage shares of particular causes of structural failures for five years. The analysis shows that the greatest number of them (over 66\%) is created during the maintenance of the building. The least number of structural failures arises due to mistakes in the preparation of the construction documentation $(7,93 \%)$. 


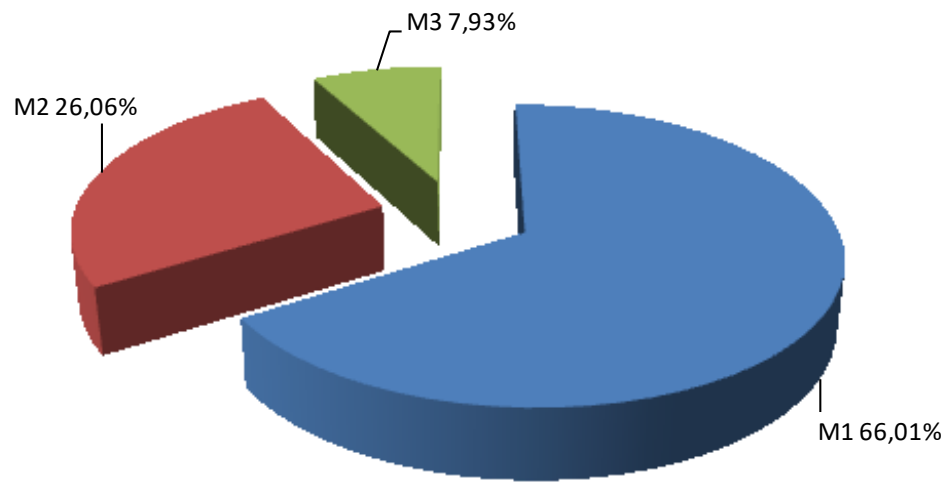

Fig. 2. Structural failures caused by human mistakes at the main stage of the construction life cycle.

The second criterion is the occurrence of structural failures while carrying out works on the building site. We take it into account type of works conducted in the area of the building site.

We analyze three areas of structural failures here:

- mistakes while carrying out works in an existing building,

- mistakes during the construction of a new building,

- mistakes during the demolition of the building.

The number of failures created during the construction works for $2013 \div 2017$ is presented in Table 2 and Figure 3.

Table 2. Failures occurred while carrying out works in a construction facility.

\begin{tabular}{|c|l|c|c|c|c|c|}
\hline Symbol & \multicolumn{1}{|c|}{ Kind of mistake } & 2017 & 2016 & 2015 & 2014 & 2013 \\
\hline M1 & $\begin{array}{l}\text { mistakes while carrying out } \\
\text { works in an existing building }\end{array}$ & 22 & 10 & 20 & 61 & 11 \\
\hline M2 & $\begin{array}{l}\text { Mistakes during the } \\
\text { construction of a new } \\
\text { building }\end{array}$ & 10 & 7 & 6 & 37 & 4 \\
\hline M3 & $\begin{array}{l}\text { Mistakes during the } \\
\text { demolition of the building }\end{array}$ & 5 & 1 & 4 & 11 & 4 \\
\hline
\end{tabular}

The analysis of the Figure 3 shows that over 58\% of all structural failures in 2013-2017 were caused by human mistakes while carrying out works in an existing building. Over $30 \%$ of structural failures are caused by mistakes during the construction of a new building. 


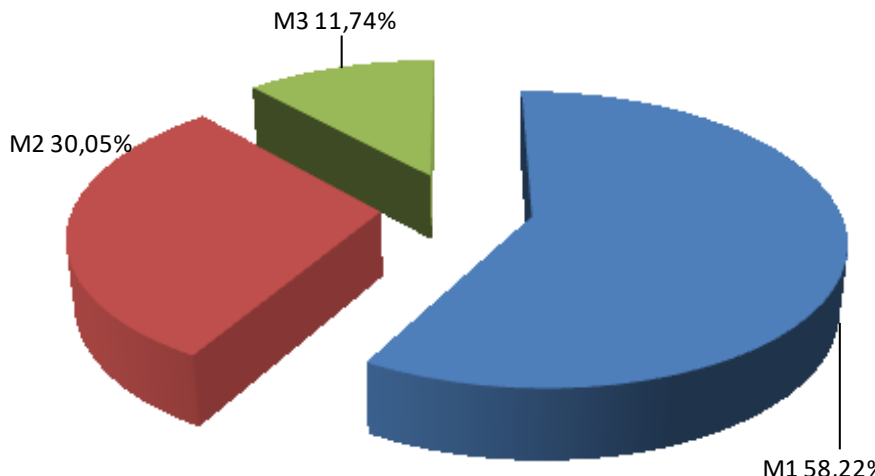

Fig. 3. Structural failures occurred while carrying out works in a construction facility.

The data from the Central Office of Construction Supervision (COCS) for the period of five analyzed years shows that thirteen most common causes are responsible for structural failures. They are listed in Table 3.

Table 3. Causes of a structural failures in 2013-2017

\begin{tabular}{|c|c|c|c|c|c|c|c|}
\hline \multirow[t]{2}{*}{ Areas } & \multirow{2}{*}{$\begin{array}{l}\text { The } \\
\text { cause } \\
\text { symbol }\end{array}$} & \multirow[t]{2}{*}{ Causes of a structural failures } & \multicolumn{5}{|c|}{ Years } \\
\hline & & & 2013 & 2014 & 2015 & 2016 & 2017 \\
\hline \multirow{7}{*}{$\begin{array}{l}\text { Mistakes } \\
\text { during } \\
\text { use }\end{array}$} & $\mathrm{C}_{1}$ & $\begin{array}{l}\text { Poor technical condition of the } \\
\text { building }\end{array}$ & 42 & 32 & 32 & 28 & 26 \\
\hline & $\mathrm{C}_{2}$ & Failure to inspect the building & 16 & 11 & 6 & 13 & 19 \\
\hline & $\mathrm{C}_{3}$ & $\begin{array}{l}\text { Failure of the owner or manager to } \\
\text { take the required actions resulting } \\
\text { from the inspection of the building }\end{array}$ & 4 & 3 & 2 & 4 & 2 \\
\hline & $\mathrm{C}_{4}$ & $\begin{array}{l}\text { Failure of the owner or manager to } \\
\text { perform the required actions } \\
\text { resulting from other technical studies }\end{array}$ & & 2 & 1 & 4 & 1 \\
\hline & $\mathrm{C}_{5}$ & $\begin{array}{l}\text { Use of a building object contrary to } \\
\text { its original purpose }\end{array}$ & 1 & 3 & 2 & 1 & 1 \\
\hline & $\mathrm{C}_{6}$ & $\begin{array}{l}\text { Failure of the owner or manager to } \\
\text { meet the required obligations } \\
\text { resulting from the actions of the } \\
\text { building control authorities }\end{array}$ & 1 & 1 & 10 & 4 & 1 \\
\hline & $\mathrm{C}_{7}$ & Other mistakes during use & 0 & 10 & 0 & 0 & 9 \\
\hline \multirow{6}{*}{$\begin{array}{l}\text { Mistakes } \\
\text { when } \\
\text { building } \\
\text { a new } \\
\text { facility }\end{array}$} & $\mathrm{C}_{8}$ & Failure to comply with technology & 5 & 15 & 12 & 5 & 20 \\
\hline & $\mathrm{C}_{9}$ & $\begin{array}{l}\text { Violation of duties by participants in } \\
\text { the construction process }\end{array}$ & 7 & 20 & 13 & 4 & 14 \\
\hline & $\mathrm{C}_{10}$ & $\begin{array}{l}\text { Deviations from the construction } \\
\text { project }\end{array}$ & 0 & 1 & 0 & 2 & 1 \\
\hline & $\mathrm{C}_{11}$ & Other circumstances & 4 & 6 & 5 & 2 & 3 \\
\hline & $\mathrm{C}_{12}$ & $\begin{array}{l}\text { Non-compliance with regulations } \\
\text { regarding the use of construction } \\
\text { products }\end{array}$ & 0 & 0 & 0 & 1 & 0 \\
\hline & $\mathrm{C}_{13}$ & Mistakes in the documentation & 1 & 1 & 1 & 2 & 1 \\
\hline
\end{tabular}




\subsection{Identification of the causes of structural failures over five years using the Pareto - Lorenzo diagram}

Pareto analysis is suitable for organizing and analyzing previously collected data. It is used when our goal is, for example, to counteract negative phenomena with the highest frequency of occurrence. Pareto-Lorenz diagram is based on the empirical regularity found that in nature, technology, human activity, assumes that $20-30 \%$ of the causes decides usually about $70-80 \%$ effects $[5,7,9-10]$. Pareto-Lorenz method (ABC method or 80-20 principle) is one of the techniques that determines the measures improving the processes and the product quality by identifying the most important features (events, causes) affecting the quality [10-12]. Pareto-Lorenz diagram (Figure 4) is used to transmit a specific validity to factors causing the problem.

The table 4 shows the thirteen most common causes of structural failures. The percentages of occurrence of particular causes were calculated. Then cumulative shares were calculated.

On the basis of the data contained in Table 4 there was prepared Pareto - Lorenz diagram (Figure 4).

Table 4. Causes of structural failures with the frequency of occurrence

\begin{tabular}{|l|c|c|c|}
\hline $\begin{array}{c}\text { The } \\
\text { symbol } \\
\text { of the } \\
\text { cause }\end{array}$ & Number & $\begin{array}{c}\text { Percentage } \\
\text { fraction }\end{array}$ & $\begin{array}{c}\text { The } \\
\text { cumulative } \\
\text { frequency } \\
{[\%]}\end{array}$ \\
\hline $\mathrm{C}_{1}$ & 160 & 36.53 & 36.53 \\
\hline $\mathrm{C}_{2}$ & 65 & 14.84 & 51.37 \\
\hline $\mathrm{C}_{9}$ & 58 & 13.24 & 64.61 \\
\hline $\mathrm{C}_{8}$ & 57 & 13.01 & 77.63 \\
\hline $\mathrm{C}_{11}$ & 20 & 4.57 & 82.19 \\
\hline $\mathrm{C}_{7}$ & 19 & 4.34 & 86.53 \\
\hline $\mathrm{C}_{6}$ & 17 & 3.88 & 90.41 \\
\hline $\mathrm{C}_{3}$ & 15 & 3.42 & 93.84 \\
\hline $\mathrm{C}_{4}$ & 8 & 1.83 & 95.66 \\
\hline $\mathrm{C}_{5}$ & 8 & 1.83 & 97.49 \\
\hline $\mathrm{C}_{13}$ & 6 & 1.37 & 98.86 \\
\hline $\mathrm{C}_{10}$ & 4 & 0.91 & 99.97 \\
\hline $\mathrm{C}_{12}$ & 1 & 0.23 & 100 \\
\hline $\mathrm{Sum}_{2}$ & 438 & 100 & - \\
\hline
\end{tabular}




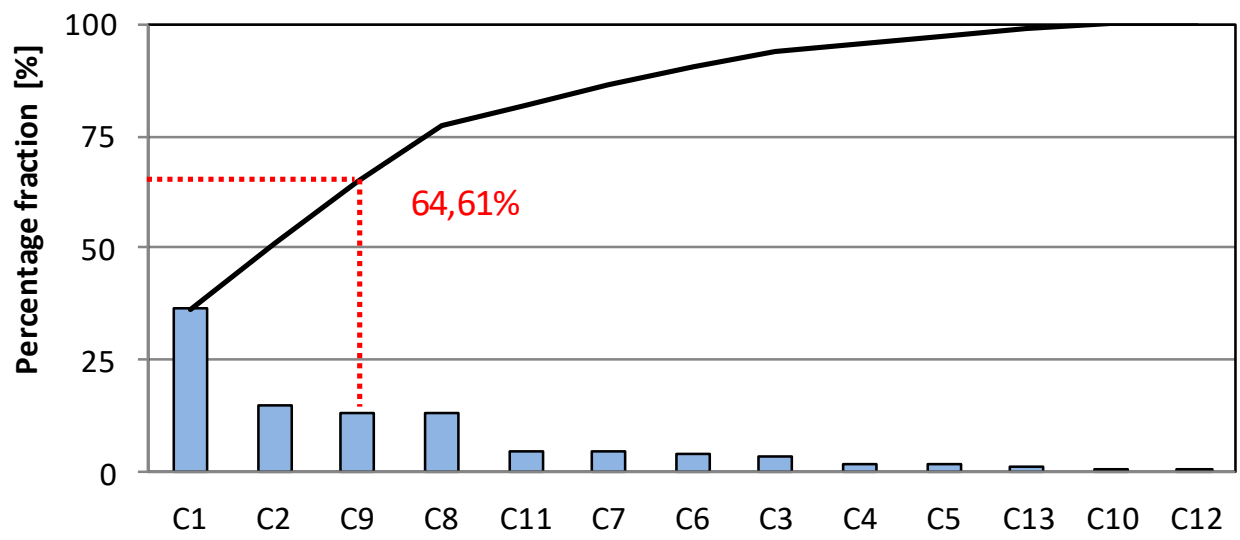

\section{The symbol of the cause of a structural failure}

Fig. 4. Pareto - Lorenz diagram for cause of the structural failures.

The analysis of Pareto - Lorenz (Figure 4) stated, that three causes are responsible for $64,61 \%$ of mistakes (structural failures). Action must be taken to eliminate the three main causes: $\mathrm{C}_{1}$ - Poor technical condition of the building, $\mathrm{C}_{2}$ - Failure to inspect the building, $\mathrm{C}_{9}$ - Violation of duties by participants in the construction process. The analysis shows that over $50 \%$ of structural failures are related to the technical condition of the building and the lack of control of the building $\left(\mathrm{C}_{1}, \mathrm{C}_{2}\right)$. The purpose of limiting structural failures should be to carry out more control of the technical condition of buildings and sanctions, which forced the owners to maintain good technical condition of the buildings.

\section{Conclusion}

The paper analyses structural failures that occurred in Poland in the last decade. Particular focus was on the structural failures affected by engineers, designers, contractors and users. It is impossible to stop the structural failures, but humans can prevent from making mistakes during the design, construction and the use of the building. The analysis shows that the most structural failures arise a result:

- mistakes during maintenance of the building (66.01\%),

- mistakes while carrying out works in an existing building (58.22\%),

- three causes are responsible for $64,61 \%$ of construction accidents $\left(\mathrm{C}_{1}, \mathrm{C}_{2}, \mathrm{C}_{3}\right)$,

- through the fault of users $(\mathrm{C} 1, \mathrm{C} 2)-51.37 \%$.

According to the Pareto - Lorenza analysis, the most common cause is poor technical condition of the building. The emphasis should be placed on more conscientious and perhaps more frequent inspections of the technical condition of the building. In accordance with Article 61 of the Construction Act, the owner or manager of a building is obliged to use the building in accordance with its intended use and environmental protection requirements and to maintain it in a proper technical and aesthetic condition. Required are measures that will force the owners of buildings to take care of the good technical condition of the buildings. 


\section{References}

1. S.M. Wierzbicki, The role of the expert in the case of building domage (Proceedings of XXV Scientific-Technical Conference on Structural Failures, Szczecin-Międzyzdroje, 2011) [in Polish]

2. M. Boryczko, Administration proceedings conducted by the building supervision authority in situation of building objects risk (Proceedings of XXVII Scientific-Technical Conference on Structural Failures, Szczecin-Międzyzdroje, 2015) [in Polish]

3. Document: Act of 7 July 1994 r. - Construction Act (Journal of Laws 2010r., No. 243, pos. 1623 with further amendments) [in Polish]

4. L. Runkiewicz, Przegląd Budowlany, 9, pp. 44-49 (2008) [in Polish]

5. J.J. Dahlagaard, K. Kristensen, G.K Kanji, Fundamentals of Total Quality Management (Taylor \& Francis e-Library, 2007)

6. Z. Hoque, Crit. Perspect. Account., 14(5), pp. 553-566 (2003)

7. J. Luczak, A. Flejszman-Matuszak., Methods and techniques of quality management. Knowledge compendium (Quality Progress, 2007) [in Polish]

8. Document: Reports of Central Office of Construction Supervision (Department of Inspection and Building Control, 2007-2017) [in Polish]

9. A. Hamrol, W. Mantura, Quality management. Theory and practice (PWN, Warszawa, 1998) [in Polish]

10. A. Czajkowska, R. Stasiak - Betlejewska, Determinants of the Machining Process in the Steel Industry (Proceedings of $25^{\text {th }}$ Anniversary International Conference On Metallurgy And Materials), Brno, Czech Republic, 2016)

11. M. Urbaniak, Management by quality, (WSB, Poznań, 2001) [in Polish]

12. R. Reed, D.J. Lemak, N.P Mero, J. Qual. Manag. 5(1), pp. 5-26, 2000 